\title{
From GWAS to genome sequencing: complementary approaches to identify melanoma predisposition genes
}

\author{
S MacGregor ${ }^{1}$, KM Brown²,9 M Stark'1, M Gartside1', S Woods ${ }^{1}$, V Bonazzi ${ }^{1}$, L Aoude ${ }^{1}$, K Dutton-Regester ${ }^{1}$, S Tyagi ${ }^{1}$, \\ J Liu', DL Duffy', J Palmer ${ }^{1}$, A Cust ${ }^{3}$, H Schmid ${ }^{4}$, J Symmons', E Holland ${ }^{4}$, C Agha-Hamilton ${ }^{4}$, K Holohan $^{2}$, \\ D Youngkin ${ }^{2}$, E Gillanders ${ }^{2,9}$, MA Jenkins ${ }^{3}$, J Kelly ${ }^{6}$, DC Whiteman ${ }^{1}$, R Kefford ${ }^{4}$, G Giles 7 , B Armstrong ${ }^{8}$, J Aitken ${ }^{5}$, \\ J Hopper ${ }^{3}$, G Montgomery ${ }^{1}$, C Schmidt ${ }^{1}$, JM Trent ${ }^{2}$, NG Martin ${ }^{1}$, GJ Mann ${ }^{4}$, NK Hayward ${ }^{1 *}$ \\ From Familial Aspects of Cancer 2011 Research and Practice: A combined meeting of kConFab, Australian \\ Breast Cancer Family Study, Australian Colorectal Cancer Family Study, Australian Ovarian Cancer Study, \\ Family Cancer Clinics of Australia and New Zealand and kConFab \\ Kingscliff, Australia. 23-26 August 2011
}

Family and twin studies indicate that melanoma susceptibility has a strong genetic component. Very rarely, melanoma runs in families in which there is an inherited mutation in a single 'high penetrance' gene, but in the general population melanoma susceptibility is thought to be governed by variation in a series of 'low penetrance' genes. We sought to identify new melanoma risk genes of both classes by conducting an Australian genome-wide association study (GWAS) of $\sim 2200$ melanoma cases and $\sim 4300$ matched controls (from the AMFS and Q-MEGA studies), in parallel with wholegenome sequencing of cases from densely affected melanoma families with follow up genotyping of interesting variants in the GWAS sample and other highly caseloaded melanoma families.

Genotyping of the GWAS sample was carried out using Illumina Hap610K or OMNI 1M arrays. All 25 SNPs that reached genome-wide statistical significance (i.e. $\mathrm{p}<5 \times 10^{-8}$ ) map to chromosomal regions/genes previously associated with melanoma (e.g. MC1R, ASIP, OCA2, MTAP/CDKN2A and SLC45A2). However, two other genomic regions had multiple adjacent SNPs with low $\mathrm{p}$ values. These were the focus of a replication study using melanoma GWAS data generated by groups from the MD Anderson Cancer Center and the International Melanoma Genetics Consortium (GenoMEL). Both independent GWAS data sets support the original

${ }^{1}$ Queensland Institute of Medical Research, Brisbane, QLD, Australia Full list of author information is available at the end of the article
Australian findings and thus indicate that the PARP1 gene and another broad region on 1q (which includes SETDB1, a recently identified melanoma oncogene) are novel low penetrance melanoma risk loci.

The three known high penetrance melanoma susceptibility genes (CDKN2A, CDK4 and $A R F)$ account for less than half of all 'familial' melanoma. We sought to identify other genes responsible for susceptibility in multicase melanoma families using a next-generation sequencing approach. Families were chosen on the basis that they did not have a mutation in CDKN2A,CDK4 or $A R F$; and had at least 5 melanoma cases. Whole-genome or exome sequencing was carried out on $\mathrm{X}$ cases from $\mathrm{Y}$ families. No convincing evidence has yet been obtained to support the identification of a new familial melanoma gene, however, follow up genotyping of several novel SNPs in the GWAS sample showed that a non-synonymous variant in the MITF gene is associated with melanoma in the general population. This type of integrated approach should help accelerate the discovery of new loci that play a role in the aetiology of melanoma.

\footnotetext{
Author details

${ }^{1}$ Queensland Institute of Medical Research, Brisbane, QLD, Australia

${ }^{2}$ Translational Genomics Research Institute, Phoenix, AZ, USA. ${ }^{3}$ University of Melbourne, Melbourne, VIC, Australia. ${ }^{4}$ Westmead Institute for Cancer Research, University of Sydney, Sydney, NSW, Australia. ${ }^{5}$ Cancer Council Victoria, Melbourne, VIC, Australia. ${ }^{6}$ Alfred Hospital, Melbourne, Australia. ${ }^{7}$ Cancer Council Queensland, Brisbane, QLD, Australia. ${ }^{8}$ University of Sydney, Sydney, Australia. ${ }^{9}$ National Cancer Institute, Rockville, MD, USA.
} 
doi:10.1186/1897-4287-10-S2-A46

Cite this article as: MacGregor et al:: From GWAS to genome sequencing: complementary approaches to identify melanoma predisposition genes. Hereditary Cancer in Clinical Practice 2012 10(Suppl 2):A46.

Submit your next manuscript to BioMed Central and take full advantage of:

- Convenient online submission

- Thorough peer review

- No space constraints or color figure charges

- Immediate publication on acceptance

- Inclusion in PubMed, CAS, Scopus and Google Scholar

- Research which is freely available for redistribution 